\title{
Evaluation of the Pain and Foot Functions in Women with Hallux valgus deformities
}

\author{
Burcu Talu', Tuba Tülay Koca ${ }^{2}$,Kezban Bayramlar³, Gül Öznur Karabıçak ${ }^{4}$
}

\begin{abstract}
Objectives: The aim of this study was to investigate whether deformity affects pain and associated functional status in women with hallux valgus (HV).

Methods: The study included 27 women (mean age: $40.5 \pm 10.3$ years) diagnosed with HV and with a deformity level of two or more as determined using the Manchester scale. Demographic data of the participants were recorded. In addition, Visual Analog Scale (VAS) was used to determine the intensity of pain during walking. To determine the function affected by pain and deformity, Foot Function Index (FFI), and the American Orthopaedic Foot and Ankle Society MTP-IP (AOFAS MTP-IP) Scale along with AOFAS Midfoot (MF) Scale were used.

Results: Based on the study results, we determined a statistically significant relationship between foot function and pain among our patients $(p<0.05)$. These significant relationships were observed between the pain and total scores of the Foot Function Index $(p<0.05)$, the pain parameter of AOFAS MTP-IP and the pain and total scores of AOFAS midfootpain scale $(p<0.05)$.

Conclusion: It was concluded that when assessing and planning treatment for hallux valgus, all health professionals dealing with foot health, pathologies, deformities and treatment should consider the patient as a whole, bearing in mind that pathologies can affect not only the perceived symptoms of individuals, but also their normal functions through various physical and social limitations. J Clin Exp Invest 2016; 7 (2): 144-149
\end{abstract}

Key words: Foot, hallux valgus, pain, function

\section{Halluks Valgus Deformitesi Olan Kadınlarda Ayak Fonksiyonları ve Ă̆rının Değerlendirilmesi}

\section{ÖZET}

Amaç: Çalışmanın amacı, halluks valgus (HV) tanısı konmuş kadınlarda ağrı ve ilişkili fonksiyonel durumu etkileyip etkilemediğini araştırmaktır.

Yöntemler: Çalışmaya klinik olarak HV tanısı konulmuş, yaş ortalamaları 40,5 $\pm 10,3$ yıl arasında olan, deformite şiddetleri Manchester skalasına göre iki ve üstünde olan 27 kadın olgu dahil edildi. Tüm bireylerin demografik verileri kaydedildi. Ayrıca, yürümedeki ağrı şiddetleri için görsel analog skalası (VAS), ağrı ve deformiteden etkilenen fonksiyon için Ayak Fonksiyon İndeksi (AFi), Amerikan Ortopedik Ayak ve Ayak Bileği Derneği- Halluks MTF-IF (AOFAS MTP-IP) ile Orta-Ayak Skalaları(AOFAS Mid-Foot Scale) uygulandı.

Bulgular: Çalışmadan elde edilen sonuçlara göre, olgularımızın ayak fonksiyonları ve ağrıları arasında istatistiksel anlamlı ilişki bulundu ( $<$ 0.05); bunlar AOFAS MTP-IP'nin ağrı parametresi ve AOFAS-Orta ayak skalasının ağrı ve toplam skorları ile Ayak Fonksiyon İndeksi Ağrı ve Toplam skorları arasındadır.

Sonuç: Ayak sağlığı, patolojileri, deformiteleri ve tedavisiyle ilgili tüm sağlık profesyonellerinin, halluks valgusa yönelik değerlendirme ve tedaviyi planlarken, hastayı bir bütün olarak ele almaları gerektiği, patolojinin bireyin algıladığı semptomlar kadar, fiziksel ve sosyal kısıtlılıklara neden olarak, fonksiyonları da etkileyebildiğinin unutulmaması gerektiği vurgulanmıştır.

Anahtar kelimeler: Ayak, halluks valgus, ağrı, fonksiyon

\footnotetext{
${ }^{1}$ Inönü Üniversitesi, Sağlık Bilimleri Fakültesi, Fizyoterapi ve Rehabilitasyon Bölümü, Malatya, Türkiye

${ }^{2}$ Malatya Devlet Hastanesi, Beydağı Kampüsü, Fiziksel Tıp ve Rehabilitasyon Kliniği, Malatya, Türkiye ${ }^{3}$ Hasan Kalyoncu Üniversitesi, Sağlık Bilimleri Fakültesi, Fizyoterapi ve Rehabilitasyon Bölümü, Gaziantep, Türkiye

${ }^{4}$ Başkent Üniversitesi, Sağlık Bilimleri Fakültesi, Fizik Tedavi ve Rehabilitasyon Bölümü, Etimesgut, Ankara, Türkiye
}

Correspondence: Burcu Talu,

İnönü Üniversitesi, Sağlık Bilimleri Fakültesi, Fizyoterapi ve Rehabilitasyon Bölümü, Malatya, Türkiye Email: fzt.burcu@hotmail.com

Received: 10.11.2015, Accepted: 09.03.2016

Copyright @ JCEI / Journal of Clinical and Experimental Investigations 2016, All rights reserved 


\section{INTRODUCTION}

Hallux valgus (HV) is a common deformity of the forefoot associated with an abnormal angulation of the big toe along the first metatarsophalangeal (MTP) joint towards the second toe. Lateral deviation of the big toe and its internal rotation along the longitudinal axis exist along with medial deviation of the 1st metatarsal bone. HV is the most common pathological condition that affects the big toe [1-4]. It is a painful and progressive disease of the big toe of gradually increasing frequency that impairs the aesthetic appearance of the foot, and severely limits the patient's daily activities if not treated. Besides pain and limitation in physical function, patients may also be affected psychologically depending on the severity of deformity [5-7].

Intrinsic and extrinsic factors have an effect on the development of HV pathology. Over-pronation or prolonged pronation of the back of foot, acquired pes planus, contracture of the Achilles tendon, increased joint laxity, hypermobility of the metatarso-cuneiform joint, familial factors, increase in body weight, gender, and certain neuromuscular disorders such as cerebral palsy and stroke are among the primary intrinsic factors of HV [8,9]. It has been noted that long-lasting activities performed while standing also increase the severity of deformity $[1,6,8,10]$. Wearing shoes with high heels and narrow toe boxes are extrinsic factors that expedite the formation of deformity and increase its severity. For this reason, HV is seen more frequently among women than men, and is more prevalent among populations wearing shoes [11-13].

The actual mechanism of HV formation has not yet been fully elucidated; however, its occurrence among populations that do not wear shoes suggests that while this deformity first develops due to an underlying mechanical cause, it becomes more severe due to a faulty choice of footwear, with symptoms increasing as a result of wearing ill-fitting footwear $[14,15]$.

The duration of daily activities performed by individuals while in standing position, their daily walking distances, and the surfaces they stand on are all important factors which determine the intensity of complaints and physical limitations. Among the different symptoms that have been reported, pain is the most significant and prevalent one. The foot has important function with regards to the sequential structure of the lower extremity. For this reason, pathologies or deformities of the foot may lead to insufficient physi- cal activity by causing pain and mobility problems in individuals. Although further studies are needed on this subject, it is generally accepted that foot and leg problems contribute to the functional impairment of physical activities $[6,16]$.

The aim of the present study was to determine the effect of clinically measured hallux valgus angle on the positional changes in the joints of the back of foot, and to investigate its effect on pain and associated functional status in female subjects with hallux valgus deformity.

\section{METHODS}

The study was initiated with 32 female cases clinically diagnosed with $\mathrm{HV}$, and whose ages varied between 20 and 54. All measurements and questionnaires were completed by 27 of the cases, while the remaining cases were excluded from the study for the following reasons: 1 case for moving to another city, 1 case because of pregnancy, 2 cases for undergoing surgical correction due to severe deformity-related complaints, and 1 case due to the non-completion of the questionnaire forms.

\section{The inclusion criteria of the study were determined as follows:}

- Female cases aged 18 to 55,

- Having right-dominance and bilateral deformities,

- I. Measured MTP joint angle above $15^{\circ}$,

- Severity of deformity of 2 and above according to the Manchester scale,

- Muscle strengths values above 4 for muscles that may lead to secondary pathological sequential disorder in the ankle and foot,

- Absence of any systemic disease that affects foot biomechanics, and absence of previous surgery,

- Absence of neurological disorders,

- Absence of cognitive, mental and psychological disorders.

Informed consents were obtained from all participants, and the study was approved by the Ethics Committee (LUT 09/37-26).

We recorded demographic data including age, height and body weight, the symptoms associated with deformity (hallux bunion and flatfoot), HV presence in family history, and the type of footwear that is commonly used. The shoes worn by the individuals 
were evaluated in 6 different groups as follows: high heel shoes, flat shoes, pointed-toe shoes, sports shoes, leather shoes and slippers.

The severity of HV deformity, which was one of the inclusion criteria, was determined using the Manchester scale developed by Garrow et al. The scale assesses the severity of HV deformity as none [1], mild [2], moderate [3] and severe [4] by comparing the appearance of the patient's foot with standardized photographs of four types of HV. It is a clinical instrument of proven validity and reliability [17]. Our cases were evaluated, and patients belonging to the first group of this scale were not included into the study. We applied the manual muscle test defined by Dr. Lovett for the muscle groups in lower extremity that may affect walking, and whose weaknesses may cause secondary pathological sequential disorder in the ankle and foot (M. Tibialis anterior, M. Extensor Digitorum communis, M. Extensor hallucis longus, M. Tibialis posterior, M. Peroneus longus and brevis, M. Triceps surae). Cases with muscle strength values below 4 were not included into the study [18].

The Visual Analog Scale (VAS) was used to determine the severity of the maximum pain felt by the cases while walking due to their deformity. The cases were asked to mark separately the most severe degree of pain they felt in the right and left feet using a 100-millimeter $(\mathrm{mm})$ horizontal line; the marked point was measured, and the value was recorded in $\mathrm{mm}$ [19]. The HV angle values, which is the angle between the long axes of the first metatarsal bone and proximal phalanx, were measured in the cases using a goniometer from the dorsum of foot, and recorded in terms of "degree (o)" [20]. Cases with a HV angles below 15o, as measured from the first MTP joint of any foot, were excluded from the study.

We used the scales prepared by the American Orthopaedic Foot and Ankle Society (AOFAS) to evaluate the functions that would possibly be affected by the associated deformity and pain; these are scales of proven reliability and validity. Among these scales, we made use of the AOFAS-Hallux Metatarsophalangeal-Interphalangeal (MTP-IP) Scale and the Midfoot Scale. Pain around the MTP joint, presence of painrelated functional effects, and smoothness of the MTP joint periphery were determined using the AOFAS Hallux MTP-IP scale. The pain, functional status and smoothness in the midfoot region were assessed with the AOFAS-Midfoot Scale. Scoring was performed between 0 and 100 points, with lower scores indicat- ing a severe deformity, and higher scores indicating a milder deformity [21].

The severity of pain felt by the cases during different activities (9 questions), the degree of difficulty they experienced during different activities (9 questions), and the associated social limitations (3 questions) were determined using the Foot Function Index (FFI). In this index consisting of three sections and a total of 21 questions, the subjects are asked to describe the score that best defines their current status, on a scale of 0 to [10]. The score of each section was calculated by summing the respective item scores of that section, then dividing the summed score by the number of questions in that section, and finally multiplying the obtained number by 100 . The total score was calculated by adding the scores of all questions of the index, then dividing the summed total by the total number of questions, and then multiplying the obtained number by 100 . Higher scores indicated a higher severity of symptoms, while lower scores indicated a lower severity of symptoms [21, 22].

\section{Statistical Analysis}

Data were analyzed using the 'SPSS for Windows Version 15' statistical software. Variables determined through measurements were expressed as mean \pm standard deviation, and the distribution of the non-numerical data were expressed as frequencies. The relationship between pain and the values of foot function was assessed using the Spearman's correlation coefficient. A p value $<0.05$ was accepted as the level of significance in the analyses.

Power analysis was performed at the end of study using the NCSS PASS 13 program; assuming that the ratio of female cases with hallux valgus corresponds to $22 \%$ of the population, and that the rate of bilateral $\mathrm{HV}$ is $70 \%$ among these $\mathrm{HV}$ cases, the sample size was calculated as 35 at a $5 \%$ margin of error and a $95 \%$ confidence interval. The power at the end of study was $85 \%$.

\section{RESULTS}

According to the demographic characteristics data obtained from the study participants, the mean age of the cases was $40.5 \pm 10.3$ years, mean height was $165.7 \pm 4.8$ $\mathrm{cm}$, and mean body weight was $69.7 \pm 11.1 \mathrm{~kg}$.

Sixteen cases $(59.3 \%)$ had a family history of HV, while 11 cases $(40.7 \%)$ did not describe any family history of $\mathrm{HV}$; when examining the presence of bun- 
ions, 18 cases $(66.7 \%)$ were identified as having bunions, while 9 cases $(33.3 \%)$ did not have any bunions. Distribution of the footwear use among the cases was determined to be as follows: 15 cases $(55.6 \%)$ used low heel shoes, 7 cases $(25.9 \%)$ used high heel shoes, 3 cases $(11.1 \%)$ used pointed-toe shoes, and 2 used cases $(7.4 \%)$ slippers.

Results of the Foot Function Index revealed that the participating individuals had the highest scores in the pain parameter, and the lowest scores in the activity limitation parameter. When the results of AOFAS Hallux MTP-IP and midfoot assessment were examined, it was observed that the cases obtained a lower score in the Hallux MTP-IP scale (Table 1).

Table 1. Data obtained from questionnaires evaluating pain and functional status the related pain

\begin{tabular}{llc}
\hline $\mathbf{n = 2 7}$ & & Mean \pm SD \\
\hline Pain (VAS) & & $53.9 \pm 22.2$ \\
Foot Function Index & Pain & $45.6 \pm 18.5$ \\
& Function & $39.8 \pm 18.2$ \\
& Activity Limitation & $23.0 \pm 9.9$ \\
& & \\
AOFAS Hallux MTP-IP Scale & Pain & $21.5 \pm 8.2$ \\
& Function & $29.3 \pm 5.3$ \\
& Smoothness & $4.8 \pm 4.0$ \\
& Total & $55.5 \pm 14.4$ \\
& & \\
AOFAS Midfoot Scale & Pain & $24.1 \pm 5.7$ \\
& Function & $28.9 \pm 4.8$ \\
& Smoothness & $8.2 \pm 1.3$ \\
& Total & $61.7 \pm 8.9$ \\
& & \\
Hallux Valgus Angle (ㅇ) & Right & $29.6 \pm 7.1$ \\
(Without weight-bearing) & Left & $34.1 \pm 6.2$ \\
\hline
\end{tabular}

SD: Standard deviation

When the relationships between the degree of pain and AOFAS Hallux MTP-IP scores, and the degree of pain and AOFAS Midfoot scores were evaluated; no significant relationship was identified between pain and the AOFAS Hallux MTP-IP scores ( $p>0.05$ ), while a moderate negative correlation was identified between pain and the AOFAS Midfoot scores ( $r=-$ $0.536, \mathrm{p}=0.002$ )

When the relationship between the degree of pain and FFI was evaluated, pain was found to be highly positively correlated with the pain parameter of FFI, and moderately positively correlated with the function parameter of FFI; there was also a positive low-level correlation between the degree of pain and the activ- ity limitation parameter of FFI (all correlations were significant; $p$ values $<0.05$ )

A moderate negative correlation was observed between the FFI and the AOFAS total scores (Table 2).

Table 2. Relationship between FFI and AOFAS scores

\begin{tabular}{|c|c|c|c|c|c|}
\hline & & & $\begin{array}{c}\text { FFI } \\
\text { Pain }\end{array}$ & $\begin{array}{c}\text { FFI } \\
\text { Function }\end{array}$ & $\begin{array}{c}\text { FFI } \\
\text { Limitation }\end{array}$ \\
\hline \multirow{8}{*}{$\begin{array}{l}\text { AOFAS } \\
\text { Hallux } \\
\text { MTP-IP }\end{array}$} & \multirow{2}{*}{ Pain } & $r$ & -0.524 & -0.534 & -0.575 \\
\hline & & $\mathrm{p}$ & 0.003 & 0.002 & 0.001 \\
\hline & \multirow{2}{*}{ Function } & $r$ & -0.215 & -0.182 & -0.170 \\
\hline & & $\mathrm{p}$ & 0.253 & 0.336 & 0.370 \\
\hline & \multirow{2}{*}{ Smoothness } & $r$ & -0.035 & 0.064 & -0.148 \\
\hline & & $\mathrm{p}$ & 0.855 & 0.739 & 0.434 \\
\hline & \multirow{2}{*}{ Total } & $r$ & -0.380 & -0.350 & -0.426 \\
\hline & & $p$ & 0.038 & 0.058 & 0.019 \\
\hline \multirow{8}{*}{$\begin{array}{l}\text { AOFAS } \\
\text { Midfoot }\end{array}$} & \multirow{2}{*}{ Pain } & $r$ & -0.522 & -0.548 & -0.432 \\
\hline & & $p$ & 0.003 & 0.002 & 0.017 \\
\hline & \multirow{2}{*}{ Function } & $r$ & -0.323 & -0.405 & -0.322 \\
\hline & & $p$ & 0.082 & 0.026 & 0.082 \\
\hline & \multirow{2}{*}{ Smoothness } & $r$ & -0.367 & -0.315 & -0.338 \\
\hline & & $p$ & 0.046 & 0.090 & 0.067 \\
\hline & \multirow{2}{*}{ Total } & $r$ & -0.498 & -0.552 & -0.467 \\
\hline & & $p$ & 0.005 & 0.002 & 0.009 \\
\hline
\end{tabular}

FFI: Foot Function Index

Table 3. Relationship between hallux valgus angle and results of the scales questioning function

\begin{tabular}{|c|c|c|c|c|c|}
\hline \multirow{2}{*}{\multicolumn{2}{|c|}{ Hallux Valgus Angle }} & \multicolumn{2}{|c|}{ Right } & \multicolumn{2}{|c|}{ Left } \\
\hline & & $r$ & $p$ & $r$ & $p$ \\
\hline \multirow{3}{*}{ FFI } & Pain & 0.515 & 0.006 & 0.632 & 0.000 \\
\hline & Function & 0.329 & 0.094 & 0.542 & 0.004 \\
\hline & Limitation of activity & 0.238 & 0.231 & 0.424 & 0.028 \\
\hline \multirow{4}{*}{$\begin{array}{l}\text { AOFAS } \\
\text { Hallux- } \\
\text { MTP-IP }\end{array}$} & Pain & -0.180 & 0.370 & -0.580 & 0.002 \\
\hline & Function & -0.226 & 0.257 & -0.167 & 0.406 \\
\hline & Smoothness & -0.023 & 0.910 & 0.047 & 0.816 \\
\hline & Total & -0.184 & 0.359 & -0.261 & 0.188 \\
\hline \multirow{4}{*}{$\begin{array}{l}\text { AOFAS- } \\
\text { Midfoot }\end{array}$} & Pain & -0.288 & 0.145 & -0.595 & 0.001 \\
\hline & Function & -0.058 & 0.775 & -0.202 & 0.312 \\
\hline & Smoothness & -0.302 & 0.125 & -0.240 & 0.229 \\
\hline & Total & -0.136 & 0.498 & -0.429 & 0.025 \\
\hline
\end{tabular}

When the relationships between the HV angles and the results of functional scales that examine subparameters such as pain, pain-related functional insuf- 
ficiency, social isolation and smoothness were evaluated; it was determined that the angular severity of left hallux valgus was positively and significantly correlated with the three sections of FFI $(\mathrm{p}<0.05)$. In addition, a positive and significant correlation was identified between the pain parameters of FFI and the right HV angle $(\mathrm{p}<0.05)$ (Table 3$)$.

\section{DISCUSSION}

$\mathrm{HV}$ is the most common pathology that leads to a painful functional insufficiency in the foot. Most studies conducted on these patients focus on findings related to decreasing the deformity and treating the disease with surgical interventions. However, the evaluation of functional status in these patients has gradually gained considerable importance. Therefore, our study focused on evaluating the pain and foot functions in female cases with HV deformity.

Our cases consisted of female individuals, since it is well-known that the rate of HV among women is 2.64 times higher than among men $[1,12]$. In the study of Mann and Coughlin, the rate of hallux valgus among women has been reported as 94\% [2]. Besides structural characteristics, this can also be due to the choices of women in wearing narrow and tight shoes $[11,15]$. Roddy et al have investigated the relationship of $\mathrm{HV}$ with age in women, and reported that the rate of $\mathrm{HV}$ was 1.76 times higher between the ages of 40 and 49 , and 3.5 times higher between the ages of 50 and 59 years of age, compared to the rates observed below 40 years of age [12]. Studies have demonstrated that the rate of deformity increases with advanced age $[23,24]$. The mean age in our study population was $40.5 \pm 10.3$ years. While, hallux valgus is more prevalent in the older population, we had not expected that young adults would be affected to this extent by this condition. This result may be associated with the existence of deformities in higher frequencies at younger ages in the gradually industrialized populations, and the gradually increasing body weights in populations while the level of physical activity is dramatically decreased.

It has been commonly reported in studies that wearing the high heel and tiptoe footwear is among the predisposing factors especially for metatarsalgia and HV deformity; in contrast to these results, we determined that only $7 \%$ of our cases preferred high heel shoes, and $3 \%$ of them preferred tiptoe shoes. This result may be related with the changes in the preference of footwear due to the pain and position of hallux in HV deformity. Furthermore, the presence of HV deformity in populations that do not wear shoes also suggests different underlying factors [8]. Other factors that are considered to cause $\mathrm{HV}$, such as the family history, presence of bunions and flatfoot, and footwear use habits have also been investigated in our study. Hardy and Clapham have reported that in $63 \%$ of the subjects with hallux valgus, HV was also present in at least one of the parents [25]. In the literature, the incidence of bunions has been reported as $94 \%$ in the mothers of individuals with hallux valgus [26]. The results obtained from our cases are in agreement with the literature.

Hallux valgus is not a simple deformity, but a complex condition that combines many abnormalities. It is relatively easy to diagnose; however, choosing the most convenient and effective treatment for the patient requires a detailed and careful investigation. Hallux valgus deformity has to be corrected, and a MTP angle of $10 \mathrm{o}-15 \mathrm{o}$ is a reasonable result; to achieve this result, the forefoot has to be narrowed surgically, the bunion pressure has to be eliminated, and the displacement of the sesamoid bones has to be corrected [26]. Before taking these decisions, a detailed pre-evaluation of the patient has to be made regarding the foot smoothness and functions. Valid and reliable scales such as the AOFAS and FFI can be used to this end.

Dawson et al. have determined relationships between complaints of pain in subjects and the AOFAS Hallux MTP-IP scores, and between complaints of pain and the AOFAS midfoot scores. We have also identified a correlation between pain and the AOFAS midfoot scores. The presence of pain in patients leads to the limitation of activities, and impairs the smoothness in the MTP joint, midfoot and back of foot. By extension, scores of the AOFAS scales that evaluate pain, function and smoothness are determined to be low. Evaluation of the AOFAS Hallux MTP-IP and midfoot scores revealed that the patients received lower scores in the Hallux MTP-IP scale; this result indicates that the big toe is affected more than the midfoot.

Our study results also revealed an association between the intensity of pain in patients and the scores of the pain and function parameters of FFI. Pain in individuals leads high scores in FFI, which evaluates pain, difficulty and insufficiency in the course of different activities.

In light of our results, the following were considered as the limitations of our study: the unavailability of a larger number of subjects with hallux valgus deformity; the lack of weight-bearing measurements and 
comparisons of the hallux valgus angle; and, although we primarily aimed to evaluate functionality, the lack of detail examination and inquiry of the pain among the patients.

In the present study, it was determined that complaints of pain increase in parallel with the increase in angular severity of the hallux valgus deformity, while the foot-specific functional status is affected negatively by pain and the progressive impairment of foot biomechanics. It was concluded that when assessing and planning treatment for hallux valgus, all health professionals dealing with foot health, pathologies, deformities and treatment should consider the patient as a whole, bearing in mind that pathologies can affect not only the perceived symptoms of individuals, but also their normal functions through various physical and social limitations. We consider that the results of the study would be a guide for the further studies on this subject.

Declaration of Conflicting Interests: The authors declare that they have no conflict of interest.

Financial Disclosure: No financial support was received.

\section{REFERENCES}

1. Coughlin MJ and Jones CP. Hallux valgus: demographics, etiology, and radiographic assessment. Foot \& Ankle Int 2007;28:759-77.

2. Coughlin MJ. Re: intra-and-inter-observer reliability of the distal metatarsal articular angle in adult hallux valgus, Chi T, et al, Foot Ankle Int. 23:722-726,2002. Foot \& Ankle Int 2004;25:443-4.

3. Bock P, Kristen KH, Kroner A, et al. Hallux valgus and cartilage degeneration in the first metatarsophalangeal joint. J Bone Joint Surg Brit 2004;86:669-73.

4. Easley ME and Trnka HJ. Current concepts review: hallux valgus part 1: pathomechanics, clinical assessment, and nonoperative management. Foot \& Ankle Int 2007;28:654-9.

5. Robinson AH, Limbers JP. Modern concepts in the treatment of hallux valgus. J Bone Joint Surg Brit 2005;87:1038-45.

6. Menz HB and Lord SR. Foot problems, functional impairment, and falls in older people. J Am Podiatr Med Assoc 1999;89:458-67.

7. Şükür E, Azboy İ, Demirtaş A, et al. Lindgren-Turan metodu ile halluks valgus cerrahisi uygulanan hastaların yaşam kalitesi. J Clin Exp Invest 2012;3:23-8.

8. Doty JF and Coughlin MJ. Hallux valgus and hypermobility of the first ray: facts and fiction. Int Orthopaedics 2013;37:1655-60.

9. Wai-Chi Wong D, Wang Y, Zhang M, et al. Functional restoration and risk of non-union of the first metatarsocuneiform arthrodesis for hallux valgus: A finite element approach. J Biomechanics 2015;48:3142-8.
10. Uchiyama E, Kitaoka HB, Luo ZP, et al. Pathomechanics of hallux valgus: biomechanical and immunohistochemical study. Foot \& Ankle Int 2005;26:732-8.

11. Yu J, Cheung JT, Fan Y, et al. Development of a finite element model of female foot for high-heeled shoe design. Clin Biomechanics 2008;23 Suppl 1: S31-38.

12. Roddy E, Zhang W, Doherty M. Prevalence and associations of hallux valgus in a primary care population. Arthrit Rheum 2008;59:857-62.

13. Dawson J, Thorogood M, Marks SA, et al. The prevalence of foot problems in older women: a cause for concern. J Public Health Med. 2002;24:77-84.

14. DiPreta JA. Managing and treating common foot and ankle problems. Preface. Med Clin North Am 2014;98: xvii-xviii.

15. Menz HB, Morris ME. Footwear characteristics and foot problems in older people. Gerontology 2005;51:346-51.

16. Talu Burcu, Bayramlar K, Bek N, et al. Validity and reliability of the Turkish version of the Manchester-Oxford foot questionnaire (MOXFQ) for hallux valgus deformity evaluation. Acta Orthop Traumatol Turcica 2015;5:123-9.

17. Garrow AP, Papageorgiou A, Silman AJ, et al. The grading of hallux valgus. The Manchester Scale. J Am Podiatr Med Assoc 2001;91:74-8.

18. Mendell JR, Florence J. Manual muscle testing. Muscle \& Nerve 1990;13:S16-S20.

19. Gallagher EJ, Liebman M and Bijur PE. Prospective validation of clinically important changes in pain severity measured on a visual analog scale. Ann Emerg Med 2001;38:633-8.

20. Deenik AR, de Visser E, Louwerens JW, et al. Hallux valgus angle as main predictor for correction of hallux valgus. BMC Musculoskeletal Dis 2008;9:70.

21. Baumhauer JF, Nawoczenski DA, DiGiovanni BF, et al. Reliability and validity of the American Orthopaedic Foot and Ankle Society Clinical Rating Scale: a pilot study for the hallux and lesser toes. Foot \& Ankle Int 2006;27:1014-9.

22. Agel J, Beskin JL, Brage M, et al. Reliability of the Foot Function Index: A report of the AOFAS Outcomes Committee. Foot \& Ankle Int 2005;26:962-7.

23. Scott G, Menz HB, Newcombe L. Age-related differences in foot structure and function. Gait \& Posture 2007;26:6875.

24. Harada K, Oka K, Shibata A, et al. [Relationships between foot problems, fall experience and fear of falling among Japanese community-dwelling elderly]. [Nihon koshu eisei zasshi] Japanese J Public Health 2010;57:612-23.

25. Hardy RH, Clapham JC. Observations on hallux valgus; based on a controlled series. J Bone Joint Surg Brit 1951;33-B:376-91.

26. Baravarian B. Hallux valgus and bunion surgery. Clin Podiatr Med Surg 2014;31: xiii-xiv.

27. Dawson J, Boller I, Doll H, et al. Responsiveness of the Manchester-Oxford Foot Questionnaire (MOXFQ) compared with AOFAS, SF-36 and EQ-5D assessments following foot or ankle surgery. J Bone Joint Surg Brit 2012;94:215-21. 